\title{
Communicating meaningfully with Muslims: Analysing the Melkite language shift in the light of Christian-Muslim relations in Northern Nigeria
}

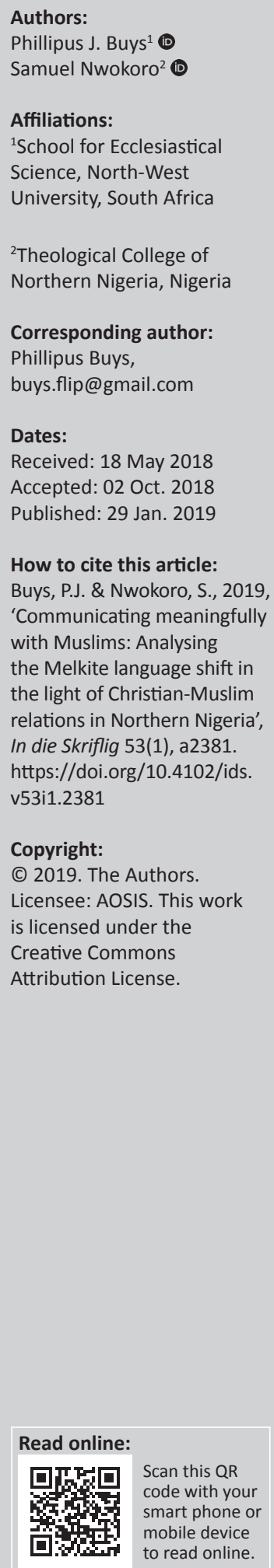

\begin{abstract}
The Melkites were one of the eastern Christian communities that came under Islamic rule following the Arab conquests. To stay in conversation with their Muslim codebaters and political leaders, the Melkites were the first among the Christian groups in the East to have their theological works appear in Arabic. One of the eras of rich interfaith exchange in the history of Christian-Muslim interaction came from this period. Today, Nigerian Christians exhibit a rising level of Islamophobia due to violent Islamic practices that have gone on in recent times. It is equally true that Muslims may have their levels of suspicion about Christians in the country. In any case, the Melkite-Muslim interfaith history indicates that there could not be a more critical time for differing faith groups to stay in communication than a period of sustained tension. Keeping this in mind, what could Nigerian Christians, in a time of interreligious relational strain, learn from the Melkites about interfaith communication? This article provides an answer to this question by drawing on lessons in the evaluation of the strategic use of the Arabic language by eastern Christian-Muslim communities of late antiquity (7th to the 10th century).
\end{abstract}

\section{Arabic during the rise of Islam}

The Melkites were Syrian Christians that held unto the Chalcedonian Christology which teaches that Christ was fully comprised of two harmonious forms - the human and the divine. The Chalcedonian creed was formulated under the superintendence of the Roman-Byzantine ecclesiastical authority (Heyer 1964:487). As most Syrian-speaking Christians were antiChalcedonian, those who confessed the Chalcedonian doctrine were mockingly called the King's loyalists, which came to be known as the Melkites. By reason of this Chalcedonian theological affiliation, Greek became the liturgical language of the Melkite community (Ter Haar Romeny 2010:233).

The conquests, following the death of the prophet Muhammad, saw to the fast spread of the language, civilisation and religion of the Arabs. Prior to this time, Arabic was an unwitten language with various dialects. A poetic version of Arabic was selected, developed and standardised under the Islamic authorities (Leaman 2006; Jeffery 2008; Versteegh 2014). This transformative process, which could be referred to as the valorisation of Arabic, involved grammatical development, lexical modification, semantic invention, and stylised expressions (Versteegh 2014; Zammit 2002). Through this development, the written form of Arab poetry was made possible and used in the making of the Qur'an (Versteegh 2014). This form of Arabic was soon cherished and protected from inadequacies, thereby shaping attitudes toward the language itself (Carter 1998).

Over time, Arabic evolved to be known as the language for class and culture. This was possible through public administration and education, among other factors. There were qur'anic inscriptions on road signs, buildings, coins and documents (Cobb 2011). There was also the monumental inscription on the Dome of the Rock in Jerusalem. The political allegiance of ruling princes to leading caliphs was secured through qur'anic citations of obedience and trust (Marsham 2009). In this way Arabic, especially in its qur'anic form, became a shaping force in the public spaces under Islamic control. In learning, basic education curriculum prioritised the memorisation of the Qur'an, learning of the Arabic script, grammar and the tafsir (Versteegh 2015). Various vernacular means of learning were soon overshadowed by this new language of literacy. Also, as parts of the Hellenised regions of Mesopotamia were conquered, Greek philosophy and science were equally translated into Arabic. This translation project took place 
in Baghdad and was spearheaded by the Abbasids in the second half of the 8th century AD.

\section{Living under Islamic rule: The Melkite experience}

All the Christian communities east of Constantinople came under Islamic rule over time. Some of these communities were the Jacobites, the Nestorians and the Melkites. The wide usage of Arabic and doing things like the 'Arabs' bred a form of 'enculturation' that highly affected ordinary Christians, much to the concern of the church authorities (Griffith 2008). By the end of the eighth and the beginning of the ninth centuries, the 'political control' of Islamic caliphs had spread from 'Spain to eastern Iran', the world under the control of Islamic religious civilisation was in every way easier to be shaped by Islamic culture (Vila 2003:35-46). The experience of Latin-speaking Christian communities under the influence of the Islamic culture in al-Andalus is analogous to those of the Syrian Christians in the East (Tieszen 2013). As Muhammad A.S. Abdel Haleem (2011) rightfully asserts, 'wherever Islam went it took Arabic with it'. Ninth century Cordoba was already flourishing with Islamic culture, such that apart from being a socially reputable thing to imitate Arabness, it was even economically convenient and socially rewarding to convert to Islam: many were either converting to Islam or neutralising their Christian identity by mingling with and observing Islamic customs (Tieszen 2013). This is indicated in the decrying of the situation by the Iberian theologian and author Paul Alvarus (d.861) as quoted by Tieszen (2013):

The Christians love to read the poems and romances of the Arabs; they study the Arab theologians and philosophers, not to refute them but to form a correct and elegant Arabic. Where is the layman who now reads the Latin commentaries on the Holy Scriptures, or who studies the Gospels, prophet or Apostles? Alas! All [sic] talented young Christians read study with enthusiasm the Arab books; they gather immense libraries at great expense; they despise the Christian literature as unworthy of attention. They have forgotten their language. For everyone who can write a letter in Latin to a friend, there are a thousand who can express themselves in Arabic with elegance and write better poems in this language than the Arabs themselves.

Church authorities in the East were apprehensive in a similar way over their followership. They used excommunication as a deterrent to inordinate mingling with Muslims (Griffith 2008). The leaders preferred that religious boundaries were kept and not indiscreetly crossed. Keeping religious boundaries in a society dominated by the language of a rival religion, however, was unhelpful. A more realistic and engaging standpoint was eventually developed by the Christians. Christian theologians became more involved in communicating strategically with Islamic leaders and thinkers. All the various Christian communities tried to answer the questions put to them by the Muslims. Writing was a major means through which the responding was done. At the initial stage, most religious writings of the kind were majorly in Syriac or in Greek.
Engaging the Muslim theologians in a language other than Arabic may not have been so effective because Arabic had dominated how reason was constructed and communicated. Early Syrian theologians such as patriarch Sophronios of Jerusalem (d.c.639), Anastasius of Sinai (d.c.700) and St. John of Damascus (wr.730s) had written and debated in Greek (Hoyland 1997). But as time went on, it became increasingly clear that non-Muslim faith communities that could not speak Arabic had to use a 'good, clear Arabic' to explain and defend their faith before the 'Arabic-speaking Muslim intellectuals' (Griffith 2012:413-443).

The work of the Melkite theologians were the earliest documents to testify to this important language shift. Melkite Christian theology began to appear in Arabic around the late 8th and early 9th century (Awad 2015; Bertaina 2008:17-36; Griffith 2002; 2008; 2012:423). The Melkites had a strong presence in Palestine and across Syria, they had an unrivaled control of monasteries within and around Jerusalem, and they had the advantage of monastic theological intellectuality (Micheau 2006). Dossiers of church matters regarding a conflict between the Melkite patriarchs of Antioch and Damascus reveal that by the 9th century, there were Melkite patriarchates in Damascus, Jerusalem, Alexandria, and Antioch (Lamoreaux 2010). Each of these patriarchates had their ranks of bishops, notable members of laity, and good sources of income (Lamoreaux 2010). So, by the time it appeared pertinent for the Melkites to articulate and defend their faith in Arabic, they had some economic, structural, theological and demographic stamina.

An anonymously authored text from the Melkite faith group, agreed to have been from the late 8th century, which is now known as On the Triune nature of God, epitomises this strategic linguistic shift (Monferrer-Sala 2010:195-197). It is the first known Christian theological text in Arabic that precisely engages the sacred-texts of Christianity and Islam in a clear attempt to endorse Christian beliefs (Griffith 2006). It bears numerous qur'anic citations, which would be a typical feature of subsequent Melkite apologetic documents, and it leaves no doubt that Muslims and Arabic-speaking Christians were its target audience (Griffith 2008; 2014:251). It has been strongly suspected that one of the monks from the Melkite controlled monasteries within and around Jerusalem may have authored the piece (Griffith 2008). However, the first notable Melkite writer in Arabic is known to be a monk from the Mar Sabas monastery and a one-time bishop of Harran, Theodore AbūQurrah (d.820; Griffith 1997:11). AbūQurrah was one of the foremost Arab Christian theologians to take on the 'formidable apologetic task of expounding Christian doctrine in an intellectual milieu dominated by Islam' (Griffith 2002).

\section{Analysing the language shift in Melkite Christian theology}

The Arabisation of Melkite Christian theology is a strategic language adoption process that could be analysed in three ways: (1) to preserve, (2) to redefine, and (3) to explain the 
Melkite Christian heritage. These three points are discussed through certain sociolinguistic thoughts.

\section{Language shift as a mode to preserve religious identity}

Andree Tabouret-Keller had suggested that language and identity are mutually related, such that the choice of language in speech can be an attribute of the speaker's identity (Tabouret-Keller 1997). Extended to Ben Rampton's language crossing theory, it can further be said that an identity which derives from a speaker's language choice affects how the speaker is accepted by an audience (Rampton 1999:54-56). One of the reasons for language switching has been underlined by Jennifer Miller to be the need for legitimate recognition, such that members of a minority language community often adopt a standard language for them to be heard and respected (Miller 2004). Arabic was a strong and pervading language which became a force in the spreading of the Islamic civilisation within late antique East and beyond. It is expected that preserving the identity of the Melkites as a minority Christian group would require cohesion building through emphasising the group's vernacular. But after a period of resistance toward Arabic and sanctions on community members who patronise Muslims, the Melkite religious authority began to use Arabic in Christian education and in church life.

The anonymous author of Summary of the ways of faith, which is a 9th century Melkite document on issues of ChristianMuslim relations of the time, mentions the formidability of Islam and how the Islamic communication about Allah is done in 'a clear language which the broad mass of people understand' (Griffith 2008). The author's further clarification on the meaning of the Christian creed indicates that there were either Arab-speaking Christians who hardly discerned any difference between their monotheistic creed and that of Islam, or Tthere were also those, who simply tried defusing their Christian identity in order to get a share of the social benefits of being Muslim, thereby seeing no harm in reciting the Islamic shahädah (Griffith 2008). The author uses strong words such as 'hypocrites' in condemning such actions and the author further addresses the issue of Arabisation, especially among younger Christians who were highly oriented toward the fashionable Arab culture (Griffith 2008). It seems that Melkite theologians saw the need to use Arabic in cautioning a younger generation of Christians born into the Islamic civilisation and that simply came to unsuspectingly embrace being Arab.

Apart from rescuing a posterity that was fast losing its Christian heritage, adopting the Arabic language made the Melkite faith identity to be preserved as an Arabic-speaking non-Islamised faith community. In David Vila's scrutiny of two hagiographical accounts, one being the Twenty martyrs of Mar Saba and the other being the Arabic account of the Martyrdom of Rawh al-Qurayshi, he indicated that while there is a radically harsh portrayal of the Arabs and the Muslims in the former text, a Byzantine text, the Arabic account of
al-Qurayshi bore an underlying mixture of Christianity and Arabness. Arabness is here used to endorse and recommend Christianity to the reader (Griffith 2008). Al-Qurayshi is portrayed as a descendant of the noble tribe of the Islamic prophet. This prophet converts from Islam to Christianity through baptism, witnessed a remarkable miracle in the hands of an iconic Christian leader, had a vision, exhibited bravery by refusing to recant his faith before Caliph HārūnAr-Rashīd, and then was executed as a Christian martyr (Vila 2001). Vila concludes that the character of a Qurayshi Arab convert who dies for the Christian faith, is a significant way of promoting Christianity within an Islamic context (Vila 2001). Making a case for Christianity by using some Arabic and Islamic icons in literary works, expresses how the Melkite Christian identity infiltrates into the linguistic and cultural tide of its time, thereby guaranteeing its relevance and subsistence.

\section{Language shift to redefine religious identity}

Defining the Melkite Christian faith in a new religio-cultural civilisation, is what is referred to as a redefinition of religious identity. It involves clarifying the essential elements of the faith in a new language and correcting the notion of dissenters. Defining Melkite Christianity in Arabic meant that the Chalcedonian theological heritage, earlier composed in Greek, was to be translated into Arabic, a language that has no provision for words like hypostasis, prosopon, ousia, or logos (Awad 2015). It was needful to make the details of the Chalcedonian faith clear to both Islamic interlocutors and even the Arabic-speaking Melkite Christians themselves. To a large extent, this process required thinking in Greek and writing in Arabic. The active proficiency in Greek and Arabic made the Melkites a redefined group: a Greekrooted but Arabic-speaking Christian community. This is an unprecedented identity modification.

Having a Christian tradition that is rooted in a bilingual theological process, meant that Melkite authors were exercising competence in two language worlds (Canagarajah 2004:285). Authors able to utilise a formal writing skill in more than one language, can have the advantage to reach out to various categories of audience and make a wider contribution (Canagarajah 2004). Such authors also may create a dialectical rather than a dichotomised manner of discourse with both languages. For AbūQurrah, a lexical creativity in Arabic for doctrinal words like incarnation would be the trilateral root word hulūl which means 'indwelling', implying the occupation of human likeness (Canagarajah 2004). A synonym to hulūl in AbūQurrah's theology would also be another trilateral root word hijāb, which when considered as the fleshly covering of the divine inhabitant, could translate as 'veiling' (Canagarajah 2004). The author of the late 8th or early 9th century document, Answers for the Shaykh, also uses the veiling metaphor for the incarnation as a 'concealment' of Jesus within Mary (Griffith 2006). Using the Arabic word hulül as 'indwelling' or 'inhabiting' may not be a perfect representation of the 
Chalcedonian exegesis for hypostasis or 'enhypostaton', which may rather connote 'embodiment' (Awad 2015).

Some of the notions that the Arab-Muslims had about Christianity was effectively corrected by the Melkites through the use of Arabic. Muslim scholars often alleged that it was at church councils, which were mostly summoned by emperors, that the distortion of Christian theology began, culminating in the deification of Christ (Griffith 2002). To make a case for the church councils was a task evident in the works of Theodore AbūQurrah and the anonymous author of Summa Theologiae Arabica among others (Griffith 2002). Those Melkite authors argue that collegial decisions regarding the Christian faith was a tradition rooted in the Bible, from the time of Moses to the apostles, and that no individual had a monopoly over Christian doctrine (Griffith 2002). They further emphasise how conciliar decisions were representative of the voice of the Holy Spirit. They emphasise also that secular leaders who facilitated the convening of these councils, were only instrumental in achieving the stability necessary for the inspired theologians and bishops to set out the creeds they deemed right for the church (Griffith 2002). Defending the conciliar traditions to which they subscribed was an important way of making the Melkite faith clear and redefined in Arabic.

\section{Language shifts as an apologetic strategy}

The Melkite authors' use of Arabic was an approach that enabled a respectful interreligious communication in which the Muslim holy book was often used to buttress arguments for the Melkite creed. Using a qur'anic exegetical interpretation to defend Christianity made the Islamic theologians to tread with caution so as not to contradict their holy book (Wilde 2014). Christians were often accused as being guilty of shirk, which literally translates as 'replacement', implying the idolatrous replacement of God by the human figure of Jesus Christ, who Melkite Christology deifies (Awad 2015). Theodore AbūQurrah, in responding to such accusations, uses qur'anic citations to build up arguments that culminated in the idea that the Qur'an 'distanced the Nazarenes [Christians] from shirk [replacing God with others] and exculpated them from unbelief when it [the Qur'an] attributed to them honor and merit (Awad 2015). AbūQurrah does this manner of comeback on the doctrines of Trinity and the Incarnation as well. To create a qur'anic justification for the teaching of the Trinity, AbūQurrah draws on passages like Q.3.45 and Q.4.171 where 'İsāibnMaryām is referred to as God's Word and Spirit. This was a deliberate use of a qur'anic text on plurality as a 'logical tenability of the pluralism in the Christian reference to God as the Father, the Son and the Holy Spirit' (Awad 2015).

With regard to the doctrine of the Incarnation, AbūQurrah begins by agreeing with qur'anic emphasis on the 'infinite transcendence and incomprehensibility' of God and on that basis he argues that the possibility of God taking a human form was an act of 'divine mercy and benevolence', which is equally a miraculous fulfilment of Q.19.17 that says 'and we sent to Maryam from our Spirit, and it appeared to her in the image of a normal human' (Awad 2015). Apart from this qur'anic passage, there are three other points with strong qur'anic allusions in AbūQurrah's defense of the Incarnation doctrine. The first is the greatness of God which the Qur'an is replete with. The second is the mercy and the benevolence of God which are qur'anic attributes for God. The third is the miraculous descent of the Son of God, coated in human form, which AbūQurrah deems as akin to the miraculous descent of the holy Qur'an itself.

\section{Christian-Muslim relations in Northern Nigeria}

As already indicated, the using of a new language to define and commend the Melkite Christian faith to refuters, was an important means of preserving the Melkite religious identity in an environment dominated by a rival religious group. How does this apply to Nigerian Christianity when it comes to coexisting and communicating meaningfully with Muslims, especially in northern Nigeria? The three elements, viz. identity preservation, identity redefinition and faith communication are used to provide an answer to this question.

\section{Identity preservation}

There had been a Chalcedonian doctrinal subscription that served as the historical backdrop to the process of Melkite identity preservation, thereby delineating what was to be preserved. In this way, religious identity is not sustained in a historical vacuum. The history that Christianity and Islam share in Nigeria, is key to understanding the nature of modern day interaction between the two. But more importantly, the missionary character in the story of the coming of Christianity is instructing for contemporary Christians in northern Nigeria when it comes to preserving the Christian identity.

Unlike the Melkites who witnessed the rise and domination of Islam over them in their own homelands, Christian missionaries found Islam being practiced in some of the places that became northern Nigeria. During the 19th century, Samuel Ajayi Crowther's account of his encounter with local kings and their councils, including mallams, shows how he respectfully explained important aspects of the Bible to them, and answering their questions through the text (Crowther 1872). By the 20th century, Protestant missionaries, following the clarion call of Karl Kumm, poured into the northern region of Nigeria resiliently establishing mission stations, medical facilities, and schools across Muslim and non-Muslim areas. The Roman Catholic missions eventually joined this effort beginning from the Shendam area of Plateau state. The Christianity that came to northern Nigeria, was in a way the religion that meets Islam as an existing religion. The carrying out of Christian missionary activities within and beyond Islamic domains, largely defines Christianity in northern Nigeria as insistently evangelistic in character but confrontational in the eyes of Islam and its 
Hausa-Fulani leadership. This would mean that Christianity in northern Nigeria is best preserved by the accepting of this 'controversial' history and an embracing of the missionary zeal central to it.

Christianity from the start positioned itself to interact with Islam. As a different religion, it was easy for Muslims in northern Nigeria to see Christian activities through the lens of rivalry. Using education as an example, communities in northern Nigeria had qur'anic schools and traditional genderrole mentoring as the two major systems of child development before the colonial period (Usman 2014). Western education came to northern Nigeria during the first decade of the 20th century, which is around the same period when the northern protectorate was put in place by the British (Usman 2014). The first school in Maiduguri was built in 1915 (Usman 2014). Schools were built by both Christian missionaries and the colonial administrative authorities. Reading and writing in schools were done majorly in English and Hausa (Usman 2014; Warren-Rothlin n.d.). The Arabic script, which was a common system of writing prior to this time, was abandoned mainly because the Protestant missionaries persuaded the colonial authority that the adoption of the Roman script would be more beneficial in the accessing of wider literary traditions (Crampton 2004:99). Although Christian missionary activities were stalled from getting into strong Islamic areas of the north for a long time, and government schools were clearly made non-Christian, most Muslims still felt that the link between formal education and Christian mission agencies, as was the case in the southern region, was indicative of some kind of hidden plan to proselytise Muslim school children (Imam 2012:182; Umar 2002:86). This suspicion was also justified by the fact that mission schools would not entirely sever religious intentions from school activities. Overall, Qur'anic schools already existed as a form of religious learning, to which other forms of learning could not be more rivalrous.

Seeing Protestant missionary campaigns as the religious movement that chipped away at the Hausa Fulani hegemony and the territorial legacy of the iconic Usman, Dan Fodio continues to shape the narrative of radical Islam in Nigeria today. This perspective accounts for the way certain members of the Islamic community react toward Christianity. The Salafi sect in Islam sees itself as endowed with the task of restoring true Islam in Nigeria (Hill 2010). Its members often accuse the Sufi elites and the Sardauna of being in passive alliance with corrupt national political authorities, who are regarded as easily prone to liberalism from the West. Forming various groups that focus on campaigning for the supreme place of the Qur'an and the tradition of the prophet, is central to Salafi methodology. Groups like Jama'atul Izalatul Bid'ah Wa'ikhamatul Sunnah (Izala) was founded by Salafi leaders like Shaikh Abu BakrGummi in 1922-1992 (Hill 2010). An offshoot of the Izala group emerged in 2004, officially known as Jama'atuAhl us-Sunnalil-'Dawawal Jihad (JAS), but commonly called Boko Haram, under the leadership of a long standing Salafi student, Muhammad Yusuf.
Boko Haram has in the last two decades, systematically recruited agents and executed terror on persons and places they deem to be enemies of the Islamic faith.

As radical Islam expresses deep sympathy for how things were before the coming of Protestant Christianity, and to some extent Colonialism, Christians continue to bear the brunt of its assaults. Also, associating Christianity with all that stands against Islam, especially modern culture and civilisation, adds to the intolerance. Preserving the Christian faith in such a context must begin with a realisation of the controversial status that the Christian history in northern Nigeria attracts for modern day Christians; an acceptance of the missionary intention that is central to the Christian heritage in northern Nigeria; and a defining of what Christianity really is, despite situational history.

It is important for Christians in northern Nigeria to acknowledge the nature of the encounter between missionaries and the existence of Islam in northern Nigeria. It was a deliberate intention for missionary presence to curb the spread of Islam. This strategic positioning may have been regarded as timely and biblically justifiable by the Great commission, but it was also highly controversial for Muslims. Accepting that Christianity was confrontational to the spread of Islam from the start, is the beginning of embracing the historical antecedence to Christian-Muslim relations today. Equally connected to this realisation is being receptive to the evangelistic motif that laid at the heart of Protestant missionary activities and acknowledging that to be an active part of contemporary Christianity.

With the above realisations, the identity of Christianity in northern Nigeria is seen as closely attached to resilience and evangelism. The birth of Christianity in the northern region would not have been possible were it not for these two qualities. They remain at the heart of Christian identity and sustainability. But there is a need to rightly define what Christianity essentially is, in the light of history and current happenings. What follows is an observation of the need for the redefinition that is central to communicating effectively with Islam in northern Nigeria.

\section{Identity redefinition}

In the study of the media communication by certain Salafi groups in Nigeria, the problem is often indicated to be Christians, the West or America and democratic institutions in Nigeria (Aworo-Okoroh 2016:133-143). To radical Islam, talking about Christianity in Nigeria often goes with mentioning secularism, liberal democracy and Westernisation, not minding that Christianity originates from the Middle East. Additionally, Islam appears in the Nigerian constitution severally, including the approval for the Sharia system as binding over identified members of the Islamic Umma. The Christian equivalence of such constitutional provision does not exist, not even a mention of the Christian religion is made in the Nigerian constitution. 
The reasons behind an undetached view of Christianity and Western culture may be obvious. Some justification for this view may derive from the historical situation described in the coming of Christianity to West Africa. Additionally, Christianity had been a major shaping force in the making of western civilisation. It is equally easier to see an acceptance of modern lifestyle and technology among Christians, as a sign of progress and civilisation. However, is Christianity actual synonymous to Westernisation? The extent to which the African identity was abandoned for those of the European or American missionaries in the name of converting to the Christian faith, may warrant seeing the Christian identity as European or American; but trading native identity in this way is equally evident in Islam wherein Arabness defines a true Muslim.

Nonetheless, indications are stronger that there is something essential to the Christian faith which does not depend on any culture. In his book, Liberating the gospel, David Smith mentions how a critical distinction that needs to be made by contemporary Christians is to separate between the dispensable wrapper formed over the past few centuries by modernist culture' and 'the radical gospel of Jesus of Nazareth' (Smith 2016). For Christianity in Nigeria, particularly the northern region, this would mean unwrapping the core message of Jesus Christ from the culture of its western harbingers and upholding it as the only essential element. This is central to the redefinition process that is necessary for engaging Islam communicatively.

\section{Communicating the faith}

Making the deliberate effort of emphasising the essential meaning of the Christian faith to the surrounding Muslim populace, is a sustaining of the missionary fervor in the Protestant Christian heritage. This promises to be a vindication of the faith from all convolution, particularly the notion of territorial domination and rivalry. While native homelands should legally remain the rightful place for native habitants, irrespective of creed, the Christian faith must be emphasised for what it is and how it shapes the life of Christians.

From the Melkite history, Scripture was central to the verbal and written interaction with the Muslim theologians. The Melkite Christian scholars, as earlier stated, used qur'anic citations, attributes for God and intertextual parallels between the Bible and the Qur'an to make a case for the Christian faith. Native missionary forbears in Nigeria like Samuel Ajayi Crowther, equally exemplified such scripturebased interaction in encounters with Muslims. In his account of one such an occasion with a Muslim leader and his followers, Crowther (1872) records:

The readiness with which I turned to passages in the Bible to answer any question put to me, without hesitation, rather astonished them. There was no argument, no dispute, no objection made, but questions asked and answered direct from the Word of God. After a general conversation about other matters, it was getting dark, the King expressed regret that I had not been earlier at the palace. On leaving I promised to send him a copy of an Arabic Bible, in which they would find those passages which we had referred to on this occasion in my English and Yoruba Testaments.

Making the most of existing or new dialogical platforms to respectfully talk about the gospel as what Christians truly believe, and doing so in openness to qur'anic expressions, is an effective means of concentrating on faith content, thereby minimising the tension often created by focusing on other things. Islam, like Christianity, is a scripture-based faith group. Interfaith conversations that are rooted in respectable knowledge of the Scriptures, expressed with discreteness and honesty may be the only guarantee to sustained meaningful interfaith interaction in an oft tense Christian-Muslim context as that of northern Nigeria. The gospel and the person of Jesus Christ must continue to be expressed as all that the Christian faith is about. As the posterity of mission-minded forebears, aligning with this definition and respectfully expressing it at the right occasions and in the language of the sacred-texts, is a promising means of communicating the Christian faith and preserving its legacy correctly.

Emphasising the true meaning of the Christian faith may be regarded as volatile, since it is exclusive to Islamic truth claims. But it could be said that the continued qualm between Christians and Muslims in northern Nigeria has had more to do with socio-political issues than theological. Distinguishing between the difficult socio-political reality in Nigeria, which affects both Christians and Muslims, and what the Christian faith teaches, is an important way of vindication the Christian faith in own right. This vindication presents the faith for what it really is and how it is rooted in the Bible. Relating this in a way that shows respect to an equally book-based religion such as Islam, is an important way of moving away from conflict and focusing on true faith. Promoting the need for true faith, would then be regarded as creating priority for the reveled books that lie at the core of Christianity and Islam rather than taking to arms.

\section{Conclusion}

In summary, this article has tried to answer the question about whether there are applicable lessons for contemporary interfaith relations in Nigeria, following the analyses of some of the earliest Christian-Muslim interactions in history. The late antique Christian theologians made use of Arabic instead of Greek in clarifying the doctrines of their faith to the ArabMuslim intellectuals of their day. By so doing, the Christian faith was preserved, redefined in an Islamic social context and commended respectably to dissenters.

For northern Nigerian Christianity, this historical study points at the need for an honest recognition of the controversial reputation, that the activities of the Protestant missionary forebears have in the eyes of puritanical Islam. This realisation then calls for the need to preserve the integrity of the Christian message by a distinction between westernisation, which is almost identical to Christianity in the eyes of Salafi Islam, and 
the essence of the Christian faith. This would enable the beholding of Christianity for what it is, thereby enabling, alongside other necessary efforts, the meaningful interfaith communication that is so highly needed.

With the optimism often expressed about how the future of global Christianity depends on the forceful vitality of Asian, Latin American and African Christianity, it is imperative that the Nigerian brand of the Christian faith stays increasingly loyal to the gospel of Jesus Christ. Simultaneously it must be open to valuable means of communication with its Muslim neighbours. Thinking more seriously on fruitful interfaith processes could not be more expedient with the rapid rise in population in Nigeria, which implies a rise in the desperation and economic vulnerability that often feed into religious intolerance.

\section{Acknowledgements Competing interests}

We declare that we have no financial or personal relationship(s) which may have inappropriately influenced us in writing this article.

\section{Authors' contributions}

P.J.B. was the project leader and supervisor and S.M. gathered and organised the library data.

\section{References}

Abdel Haleem, M.A.S., 2011, 'Arabic as the language of Islam', in S. Weninger, G. Khan, G. Ungeheuer \& H. E. Wiegand (eds.), The Semitic languages: An international handbook, De Gruyter Mouton, Berlin.

Awad, N.G., 2015, Orthodoxy in Arabic terms: A study of Theodore Abu Qurrah's theology in its Islamic context, De Gruyter, Berlin.

Aworo-Okoroh, J., 2016, 'Ideology and power relations in AbubakarShekau's Speech Texts', AFRREV LALIGENS: An International Journal of Language, Literature and Gender Studies 5, 33-43. https://doi.org/10.4314/laligens.v5i1.12

Bertaina, D., 2008, 'Melkites, Mutakallimūn and Al-Ma'mūn: Depicting the religious other in medieval Arabic dialogues', Comparative Islamic Studies 4, 17-36.

Canagarajah, S., 2004, 'Multilingual writers and the struggle for voice in academic discourse', in A. Pavlenko \& A. Blackledge (eds.), Negotiation of identities in multilingual contexts, pp. 271-284, Multilingual Matters, Sydney.

Carter, M.G., 1998, 'Al-Anbari, Abu Muhammad Al-Qasim Ibn Muhammad', in J.M. Scott \& P. Starkey (eds.), Encyclopedia of Arabic Literature, pp. 231-328/ 885-940, Taylor \& Francis, London.

Cobb, P., 2011, 'The empire in Syria, 705-763', in C.F. Robinson (ed.), The formation of the Islamic world, sixth to eleventh centuries, vol. 1, Cambridge University Press, Cambridge.

Crampton, E.P.T., 2004, Christianity in Northern Nigeria, ACTS, Jos.

Crowther S.A., 1872, 'Bishop Crowther's report of the Overlad journey from Lokoja to Bida, on the River Niger and Thence to Lagos on the sea coast, Church Mission House, Salisbury Square, viewed 17 October 2018, from http://anglicanhistory. org/Africa/Crowther/niger1872.html

Griffith, S.H., 2002, The beginnings of Christian theology in Arabic: Muslim-Christian encounters in the early Islamic period, Ashgate, Burlington.
Griffith, S.H., 2006, 'Answers for the Shaykh: A 'Melkite' Arabic text from Sinai and the doctrines of the trinity and the incarnation', in E. Grypeou \& M.N. Swanson (ed.), "Arab orthodox" apologetics", in the encounter of eastern Christianity with early "Arab orthodox" apologetics", in
Islam, pp. 277-310, Brill, Leiden.

Griffith, S.H., 2008, The church in the shadow of the mosque: Christians and Muslims in the world of Islam, Princeton University Press, Princeton.

Griffith, S.H., 2012, 'Melquitas Y Musulmanes: El Corán, Cristología Y Ortodoxia Árabe', Al-Qanțara 33, 413-443. https://doi.org/10.3989/alqantara.2012.004

Griffith, S.H., 2014, 'Christians and the Arabic Qur'ān: Prooftexting, polemics, and intertwined Scriptures', Intellectual History of the Islamicate World 2, 243-266.

Griffith, S.H., 2017, From Aramaic to Arabic: The Languages of the monasteries of Palestine in the Byzantine and early Islamic periods, viewed 24 September 2018 from http://www.syriacstudies.com/2017/01/23/from-aramaic-to-arabic-thelanguages-of-the-monasteries-of-palestine-in-the-byzantine-and-early-islamicperiods-\%e2\%80\%a8authors-sidney-h-griffith/

Heyer, F., 1964, 'Ecumenical mission in the Oriental church: The Melkites', Journal of Ecumenical Studies 1, 485-502.

Hill, J.N.C., 2010, Sufism in Northern Nigeria: Force for Counter-Radicalization? Strategic Studies Institute, U.S. Army War College, Carlisle.

Hoyland, R.G., 1997, Seeing Islam as others saw it: A survey and evaluation of Christian, Jewish and Zoroastrian writings on Early Islam, The Darwin Press, New Jersey.

Imam. H., 2012, 'Educational policy in Nigeria from the Colonial Era to the PostIndependence period', Italian Journal of Sociology of Education, 1(2012):182.

Jeffery, A., 2008, The Arabic Qur'ān and foreign words, viewed 22 September 2018 , https://muslimmatters.org/2008/05/21/the-arabic-quran-and-foreign-words/

Lamoreaux, J., 2010, 'David of Damascus', in D.R. Thomas, A. Mallett \& J.P. MonferrerSala (eds.), Christian-Muslim relations: A bibliographical history, pp. 900-1050, Brill, Leiden.

Leaman, O. (ed.), 2006, 'Caligraphy and the Qur'an', in The Qur'an: An encyclopedia, Taylor \& Francis, London.

Marsham, A., 2009, Rituals of Islamic monarchy, accession and succession in the First Muslim Empire, Edinburgh University Press, Edinburg.

Micheau, F., 2006, 'Eastern Christianities (eleventh to fourteenth century): Copts, Melkites, Nestorians and Jacobites', in M. Angold (ed.), Cambridge history of Christianity, pp. 371-403, Cambridge University Press, Cambridge.

Miller, J., 2004, 'Identity and language use: The politics of speaking ESL in schools', in A. Blackledge \& A. Pavlenko, Negotiation of identities in multilingual contexts, Multilingual Matters, Sydney.

Monferrer-Sala, P.J., 2010, 'Once again on the earliest Christian Arabic apology: Remarks on a palaeographic singularity', Journal of Near Eastern Studies 69, 195-197. https://doi.org/10.1086/597764

Rampton, B., 1999, 'Crossing', Journal of Linguistic Anthropology 9, 54-56. https:// doi.org/10.1525/jlin.1999.9.1-2.54

Smith, D., 2016, Liberating the Gospel: Translating the message of Jesus Christ in a globalised world, Longman \& Todd, Darton.

Swanson, M., 2001, 'The martyrdom of 'Abd Al-Masih', in D.R. Thomas (ed.), Syrian Christians under Islam: The first thousand years, pp. 277-310, Brill, Leiden.

Tabouret-Keller, A., 1997, 'Language and identity', in F. Coulmas (ed.), The handbook of sociolinguistics, pp. 15-26, Blackwell, Oxford.

Ter Haar Romeney, B., 2010, 'Athanasius in Syriac', Church History and Religious Culture 90, 233. https://doi.org/10.1163/18712411-0X542383

Tieszen, C.L., 2013, Christian identity amid Islam in medieval Spain, Brill, Leiden.

Umar, M.S., 2002, 'Islamic arguments for western education in northern Nigeria: Mu'azuHadejia's Hausa poem: "IIminZamin"', Islam et Sociétés au Sud du Sahara 16,86 .

Usman, B., 2014, Girl-child education in Biu Emirate: The early years, Abuja, Klamidas. Versteegh, K., 2014, The Arabic language, Edinburgh University Press, Edinburgh.

Versteegh, K., 2015, 'An empire of learning: Arabic as a global language', in C. Stolz \& J. de Gruyter (eds.), Language empires in comparative perspective, pp. 41-54, De Gruyter, Berliln.

Vila, D., 2003, 'The struggle over Arabisation in medieval Arabic Christian hagiography', Al-Masāq 15, 35-46. https://doi.org/10.1080/0950311032000057112

Warren-Rothlin, A., n.d., 'Arabic script in modern Nigeria', viewed 12 November 2018, from https://www.academia.edu/2244951/Arabic_script_in_modern_Nigeria

Wilde, C.E., 2014, Approaches to the Qur'än in early Christian Arabic texts (750-1258 CE), Academica Press, Bethesda.

Zammit, M.R.A., 2002, Comparative lexical study of Qur'ānic Arabic, Brill, Leiden. 